MORTALITY TABLES AND EXPECTATION OF LIFE.

IN Nature of July 6 (xcvii., pp. 383-384) reference was made to a statement by Dr. W W. Campbell, president of the American Association for the Advancement of Science, that recent discoveries in preventive and curative medicine had increased the average length of life by many years, and that the increase so caused had been great for those healthy men whose lives had been accepted as risks to be insured by life assurance companies. While it was admitted that there was a high probability in favour of that conclusion, it was also pointed out that the tables in existing use had been available for fifteen years only, and that the time had not come for them to be superseded by fresh observations. Upon this Dr. Campbell stated in Nature of September 2I (p. 48) that the data upon which those tables are founded go back to the thirty years from 1863 to 1893 , and do not therefore give full effect to the improvement in the duration of life which he believes has arisen during the last fifty years.

Observations recently made in America and in Australia have raised questions as to this alleged improvement which call for careful consideration. They affect principally the middle-aged man-that is, the man of forty years or more. They do not, therefore, directly negative Dr. Campbell's conclusion, which relates to persons under that age as well as to some above it. Dr. C. F. Bolduan, who is director of the Bureau of Public Health Education in New York, is quoted in the Lancet and the Times as having stated in an official report that the death-rate in the United States registration area at the age period forty-five to fifty-four has increased by nearly 2 per cent. during the last ten years, and that between fiftyfive and sixty-four by nearly 7 per cent. When these figures are compared with those representing the variation in death-rates between $185^{\circ}$ and 1900 , as given in Mr. Gore's report to the New York International Congress of Actuaries, they acquire some significance. That report records for ages forty to forty-nine a diminution in the rate of mortality of $7 \frac{1}{2}$ per cent., for fifty to fiftynine of $7 \frac{3}{5}$ per cent., and for sixty to sixty-nine of $6 \frac{1}{5}$ per cent. If it is the, fact that this favourable tendency has been checked at a time when not only the discoveries referred to by Dr. Campbell, but other contributory causes, such as better sanitation, have been in full operation and should have produced a further diminution in the rate of mortality, it is evident that some adverse influences are at work which ought to be investigated. Dr. Bolduan finds them in over-strain and over-eating, and a committee appointed by the Department of Trade of the Commonwealth of Australia to inquire into the causes of death and invalidity has made a report on the risks of middle age which arrives at similar conclusions.

Whether a like reaction is observable in this country may be doubted. The report of $\mathrm{Mr}$. Warner to the actuarial congress mentioned above showed that, as between the investigation of the No. 2464 , voL. 98]
Institute of Actuaries ending in 1863 (termed $\mathrm{H}^{\mathrm{M}}$ ) and that of the Assurance Companies ending in 1893 (termed $\mathrm{O}^{\mathrm{M}}$ ), the expectation of life for males uniformly increased-at age forty from $27^{\circ} 4$ years to $27^{\circ} 9$; at age fifty from $20^{\circ} 3$ to $20^{\circ} 6$; at age sixty from 13.9 to $14^{\circ} \mathrm{I}$; at age seventy from 8.5 to $8 \%$. It is unfortunate that the body of experience available relating to female mortality is insufficient for a similar comparison to be made, for there is reason to think that female life is now passed in better hygienic conditions than formerly.

The remedy suggested in America and Australia consists in a campaign against avoidable adult mortality; but there is some force in the caution of the Lancet that risk lies in the direction of faddiness.

\section{PROF. THOMAS PURDIE, F.R.S.}

THE value of a close, sympathetic relationship between professor and student is perhaps not fully recognised, and certainly can be properly appreciated only when it has formed part of a personal experience. The power of winning the affection and confidence of young men was a marked feature of the personality of Prof. Purdie, whose death was announced in NATURE of December $2 \mathrm{r}$ last; and no record of his life, however slight, would be complete without special reference to the wonderful insight and understanding that bound him to his students. During the twentyfive years he occupied the chair of chemistry in St. Andrews he devoted himself to the development of character in the undergraduate quite as much as to the simpler duty of converting him into a chemist.

Purdie's early experience in life enabled him to escape the limitations frequently imposed on the specialist. Born at Biggar in 1843 , he spent seven years of his youth in South America, where, under conditions which were always primitive and often dangerous, he lived an active, open-air life. All his time, however, was not spent in the saddle. The flora of the pampas and the minerals of the hills claimed his attention and interest, and aroused the spirit of inquiry which was never thereafter quenched. On his return to this country at the age of twenty-seven, definite direction was given to these scientific instincts by a conversation with Huxley while walking under the cliffs at St. Andrews, and probably to this impetus can be traced his subsequent career as a chemist.

After studying at the Royal School of Mines under Frankland, he went to Würzburg, where he came under the inspiring influence of Wislicenus, and a close and lasting friendship sprang up between the two men, who had much in common. His teaching experience was gained at South Kensington and Newcastle-under-Lyme, and in 1884 he was appointed to the vacant chair at St. Andrews. The University must for all time be grateful to the electors for their choice. Cramped accommodation, imperfect equipment, and the fact that chemistry had then no official 